\title{
INDONESIAN STUDENT CULTURE SHOCK IN THE REPUBLIC OF CHINA DURING THE COVID-19 PANDEMIC
}

\author{
Catur PRIYADI* and Anggia Hasti BENJAMIN \\ Department of communication University of Prof. Dr. Moestopo (Beragama) \\ *caturpriyadi11@gmail.com
}

\begin{abstract}
ABSTRAK
Many students have a goal to achieve success by getting a better education, one of the countries that is a destination for Indonesian students to study abroad is China, but the covid-19 that was endemic at that time in Taiwan made Indonesian students try to adapt to the situation. government policies and culture. The study entitled "Indonesian Student Culture Shock in the Republic of China During the Covid-19 Pandemic", aims to explain how students communicate during the Covid-19 outbreak and express students' feelings and hopes in conditions of self-quarantine and social distancing due to COVID-19. The theories used in this study include interpersonal communication, culture shock theory, phenomenological theory, the hybrid sociocultural framework theory and communication adaptation theory. This study uses a phenomenological method, a qualitative descriptive approach with a constructivism paradigm. Data was collected by interviewing four Indonesian students studying in Taiwan at two different universities. The results of the study found that the adaptations made by students from Indonesia regarding the new culture in Taiwan and the current epidemic of Covid-19 will lead them to a better communication relationship or vice versa. In terms of adapting to the new culture in Taiwan, students from Indonesia have begun to be accepted by the new environment and have felt that they have succeeded in adapting, which means they have good communication relationships with Taiwanese students and other local communities.
\end{abstract}

Keywords: Culture Shock, Students, Covid-19 Pandemic, Self-Quarantine

\section{BACKGROUND}

Students currently migrate both abroad and abroad, many of whom aim to achieve success by seeking better and quality education (Santrock, 2002). One of the countries that is a destination for Indonesian students to study abroad is the Republic of China (Taiwan). According to Samuel Wiyono, Director of the Beijing Language and Culture Institute (BLCI) in 2016, more and more students went to China to study, both for undergraduate and postgraduate degrees. The increase occurred, which was $13.6 \%$ from the previous year and it made the number of students from Indonesia reach $47.4 \%$ of all foreign students in China (Latief, 2017). The results of the 2018 SUN Education Quick Count Achievement show that there has been an increase in the number of Indonesian students studying abroad in the past year (Hidayat, 2019). The distribution of students in Indonesia alone has a total of 1,437,425 for new students, 6,924,511 for registered students, and 1,046,141 for graduating students (Badan Pusat Statistik, 2018).

Based on a study by the Indonesian Association of International Education Consultants, there are more than 35,000 Indonesian students who study abroad each year (Rahayu, 2019). The number of registered students in Indonesia is $21 \%$ more than the population of Singapore, which is $5,747,886$, of which $6,924,511$ are registered in Indonesia. Up from the previous year, new students in Indonesia currently number 1,732,308 (Badan Pusat Statistik, 2018).

Indonesian students in Taiwan carry out the government's appeal, namely self-quarantine and social distancing due to the Covid-19 outbreak. Self-quarantine is quarantining yourself by staying at home and only going to do important things, while social distancing is how to stay together but keep your distance (Sagita, 2020).
At the beginning of the appeal, Su Yufan, a student in Taipei, Taiwan, considered the appeal to have violated human rights (bbc.com, 2020). The National Sun Yat-sen University student protested via Facebook on January 28, 2020, he also sued MOE (The Ministry of Education) and asked the government to formally reply to his statement on Facebook (bbc.com, 2020).

The initial appeal from the Taiwanese government was a form of rapid response from the Taiwanese government because they had learned from the conditions of the SARS (Severe Acute Respiratory Sydrome) outbreak in 2003 (Hale, 2020). Taiwan's quick response made the country the East Asian country with the lowest Covid-19 cases, namely five cases on February 29, 2020 (Habibi, 2020). Taiwan also reported zero new cases of Covid-19 on Tuesday, April 14, 2020 and regarding this incident, Minister of Health Chen Shih-ching said that it was the first time for Taiwan that it had not had a new case in 36 days (Prima, 2020). In fact, Taiwan is the closest East Asian country to China (China), which is the country with the highest Covid-19 cases in Asia. The distance between the two countries is only $34.2 \mathrm{~km}$ or the equivalent of traveling for one hour and twenty five minutes by car, but their conditions are very different.

The chairman of the Wuhan Indonesian Student Association (PPI), Nur Musafak said that he and other Indonesian students had asked the Indonesian Embassy (Embassy of the Republic of Indonesia) to return them to Indonesia because of the Covid-19 outbreak in Wuhan, China (China) (bbc. com, 2020; Inscription, 2020). As of January 27, 2020, Nur Musafak said that the situation was not too severe, but some areas in China (China) closed some public transportation access to limit travel (bbc.com, 2020).

In addition to closing some access to public transportation, another way that China (China) has taken 
to limit travel is to enforce online education. Several universities in China (China), such as Peking University in Beijing, apply this method for one semester starting on February 17, 2020. According to Iwan Ismi Febriyanto, a graduate student majoring in Public Policy at Peking University, students can study online in four ways, including live streaming, MOOCS (Massive Online Open Courses), Webinars, and social media groups (Habibi, 2020). Iwan returned to Indonesia since January 5, 2020, at which time the Chinese government (China) had not issued an appeal against the Covid-19 virus so that Iwan could return without a hitch (Habibi, 2020). For students who have not returned to Indonesia, they are forced to do online education even though they are still in China. Not only that, they have to communicate online with their peers because of social distancing.

This Covid-19 began at the end of 2019, precisely on December 31, 2019, China (China) reported that there were several cases of pneumonia in Wuhan, Hubei Province where the cases identified the presence of the Novel Coronavirus. On January 4, 2020, WHO (World Health Organization) announced on social media that there were no fatalities in the pneumonia case, but the day after, on January 5, 2020, WHO announced that the Novel Coronavirus had spread in Wuhan. Then on February 11, 2020, WHO inaugurated that the infection caused by this corona virus was named Covid-19 (Inscription, 2020).

According to the Director General of WHO, Tedros Adhanom Ghebreyesus, "co" comes from "virus", and "d" comes from "disease" or disease, while the number 19 stands for 2019 because this infection was first identified on December 31, 2019 (Inscription , 2020). As of April 1, 2020, China (China) was ranked first in Asia with the highest number of Covid-19 cases of 81,554 cases, and was ranked fourth from all over the world (worldomater, 2020). The United States ranked first with 188,647 cases, Italy with 105,792 cases, and Spain with 102,136 cases (worldomater, 2020).

Looking at the previous research that became the reference in this research, the research entitled "Communication Adaptation in Facing Culture Shock in Overseas Students", the purpose of this research is to reveal the ways in which overseas students at Paramadina University Jakarta behave and behave when facing a new culture as a form of adaptation. The theory used is intercultural communication, culture shock and communication adaptation. The results of this study conclude that in each research subject who has a different background, they have similarities, namely in three main things that play a major role in their culture shock process, including language, lifestyle, and clothing. Although the same, these three things provide different levels of culture shock and impact on the communication adaptation process of each informant (Indra, 2015).

While in another previous study that the researcher adopted entitled "Understanding the Heterogeneity of
International Students' Experiences: A Case Study of Chinese International Students in U.S. Universities", the aim of his research is to understand diversity in South American universities through the eyes of overseas students from China. The theory used is The hybrid sociocultural framework theory. The results of this study are that there are four dominant factors that are considered by international students from China, namely communicating in English, following the curriculum, preparing plans for the future, and participating in extracurricular activities. New students and advanced semester students have different barriers because of their different priorities (Heng, 2019).

In contrast to the two previous studies above, the researcher conducted a study entitled "The Cultural Concussion of Indonesian Student Communication in the Republic of China During the Covid-19 Pandemic", with the aim of knowing how students communicate during the Covid-19 outbreak and express the feelings and hopes of students in a self-conscious condition. - Quarantine and social distancing due to Covid-19.

\section{METHODS}

This study uses a qualitative approach with a constructivist paradigm which has the assumption that no event or case occurs because of a single factor. This study uses the phenomenological method, where when examining events and their sources they experience directly. In this study, students from Indonesia were used as informants who experienced firsthand issues in related phenomena. The object of the research is the adaptation of overseas students from Indonesia in Taiwan during the Covid-19 outbreak. Meanwhile, the research subjects were informants, namely overseas students from Indonesia who studied at Cheng Shiu University and Taiwan Shoufu University.

In the Phenomenology study of changes in the way Indonesian students communicate in the Republic of China (Taiwan) during this Covid-19 epidemic, researchers took the required data from the field by means of in-depth interviews because it was considered effective in finding out an issue to sources who experienced it directly ( Creswell, 2017).

The researcher interviewed four Indonesian students studying in Taiwan majoring in Civil Engineering at Cheng Shiu University, majoring in Multimedia Design at Taiwan Shoufu University, and majoring in Hospitality Management at Taiwan Shoufu University, which were a small number of students who experienced the phenomenon under study. The questions asked are unstructured and in a free atmosphere, in this study it is useful to adjust to the situation of overseas students by eliminating the formal impression. This is useful so that researchers can be closer to informants and ask questions more freely so that they do not hesitate to answer.

The data analysis technique carried out by the researcher was to describe his experience in detail from the 
results of in-depth interviews. The results of the interviews are grouped into meaning units and then detail and write with a textural description about their experiences, including existing examples, then reflect on their thoughts and use imaginative variations or structural descriptions, look for all possible meanings through the process of divergent perspectives, consider the frame of reference for the phenomenon. , and constructs how the phenomenon is experienced, then constructs the entire explanation of the meaning and essence of the experience, and finally includes a composite description (Creswell, 2017).

\section{RESULTS AND DISCUSSION}

\section{Language Problems}

The findings from this study reveal the actual conditions experienced by Indonesian students in the midst of self-quarantine and social distancing regulations in Taiwan. In addition, this study also found various kinds of cultural shock that were almost the same for every Indonesian student, but with a different adaptation process. This study also reveals the language difficulties experienced by Indonesian students in Taiwan. Initially, these students had difficulties in communicating due to different language barriers. This is naturally an obstacle because the average Taiwanese cannot speak English and automatically makes immigrants have to be able to speak Mandarin.

"Among the biggest decisions a resident in Taiwan has to face is whether or not to attempt to learn to speak, read, or write Chinese. ”(Bates \& Bates, 2005). (Bates $\&$ Bates, 2005). The Chinese language referred to by Bates above is Mandarin because that language is the national language of Taiwan or commonly called gwoyu. Informants as students in Taiwan have to learn Mandarin. Each of them uses various ways to be able to learn. Some learn by taking courses and some selftaught through Chinese dramas or Youtube

Chinese itself is difficult to learn because it has many characters and each character associated with a different vowel will have a different pronunciation. Not only characters, the dialect in Mandarin pronunciation also needs to be considered because if the pronunciation is wrong, then the meaning will be different. While Mandarin is the national language, Taiyu is one of the dialects in Taiwan. According to the informant, it is better to learn Mandarin first because the Taiyu dialect can be learned on its own over time and also Mandarin is easier to learn and everyone in Taiwan can understand it. Bates also has the same statement that Mandarin should be learned first compared to the Taiyu dialect.

"Ability to converse in Taiwanese will endear you to the Taiwanese population and leave the Mandarin speakers confused or resentful. Fluency in Mandarin, on the other hand, will impress almost everyone; can be used throughout China; and will generally be easier to learn."
“...It is probably best to learn Mandarin first and pick up Taiwanese as and when friends teach it to you." (Bates \& Bates, 2005). When the informants could not speak Mandarin, the communication between them and Taiwanese students was hampered due to the language barrier. However, informants responded by using Google translate, Pleco, or Tandem to translate their words so that Taiwanese students could understand them and make friends. In other words, their goal of verbal interpersonal communication in the form of writing is in line with one type of interpersonal relationship, namely the need for affection. Friendship is included in the category of need for affection because according to Schutz, friendship is an example of positive emotions or feelings (Wulandari \& Rahmi, 2018).

Informants also studied Mandarin to learn about the new environment in order to understand the culture in it. The importance of language is in line with Bates' statement. "The decision to learn the language should not be taken lightly, but it will reap rewards for you in terms of your cultural understanding, the depth of friendships you can develop, and the ease with which you can move through otherwise complex and frustrating situations. "(Bates \& Bates, 2005).

\section{Culture Shock Phenomenon}

The experience of culture shock is a normal thing experienced by overseas students, both new students and advanced semester students (Devita et al., 2015). In accordance with this statement, this study also reveals about the culture shock experienced by new semester and advanced semester students studying in Taiwan.

In terms of friendship, Taiwanese are touchy individuals or like skin ships (touch). However, the informant revealed that Taiwanese people did not shake hands when they met. In contrast to Indonesian culture, this often makes informants awkward when they meet Taiwanese people. It turns out that Taiwanese people tend to be stiff in making acquaintances, they only like skin ships when they are with people who are really familiar.

"Depending on the culture you come from, you may find Taiwanese personal distance uncomfortable. The Taiwanese do not mind sitting close to someone and if you are a friend (man to man, or woman to woman) they might occasionally touch your hand or take your arm. Do not be alarmed; this is not a homosexual advance, jus a gesture from a person who comfortable enough with you to get that close. It means that you are making progress. Among students or old folk, you will frequently notice members of the same sex walking arm in arm, or sometimes holding hands. This is not abnormal; the contact is gentle and subtle. However, they do not like loud, back-slapping, bear-hugging, cheek-kissing contact of the sort at which some Americans and Europeans excel" (Bates \& Bates, 2005). 
Taiwanese culture and Indonesian culture are very different. Being in a new culture, informants see culture as behavior or habits that exist in a society. Agreeing with this opinion, the author sees culture as the identity of a particular group that is characteristic to stand out from other groups. According to the informant, culture as an identity is important because it can distinguish the culture of a certain group from the culture of other groups. Informants assume that when someone is in a new environment, then they must learn the culture in order to understand and enter into that environment. It can also be said that culture is part of an environment. The informant's expression about the meaning of culture is in line with Carl J. Warden's statement in his book entitled The Emergence of Human Culture.

"As a matter of fact, mankind has been enmeshed in an artificial environment for so long that many cultural traits have become second nature to him. In the process of self-domestication, the so-called natural man gave place to a new type of being. Cultural and biological forces are now so interpenetrated that logical separation is almost impossible" (Warden, 1936).

One of the cultures in Taiwan is that every newcomer must change his name to a Chinese name. This is because Chinese characters cannot pronounce some common vocabulary so newcomers have to change their names. Each informant also has a Chinese name, where one of the two informants already had that name before coming to Taiwan because the informant was of ChineseIndonesian descent. In line with Bates' statement about foreigners adopting Chinese names in Taiwan, the author finds that this is not a new culture in Taiwan. "Foreigners often choose Chinese names, but if you want one it must be chosen carefully; you will have it for a long time, it will leave an impression (good or bad), and may even say something rude about you if you are not careful" (Bates \& Bates, 2005).

Individuals who are in a new environment will experience culture shock. Culture shock is a sense of hopelessness, excessive fear, and a desire to return to home. This is due to a sense of alienation and solitude caused by the clash of cultures. This culture shock has several stages, namely the honeymoon period, the crisis period, the recovery period, and the adaptation period.

The first time students from Indonesia were in Taiwan, they had a happy feeling. Two informants are excited to do their studies in Taiwan, while one informant is excited for a different reason, namely wanting to visit new places. This stage is in line with Indra's expression about the honeymoon period regarding the U-curve of the Samovar. "This stage is the introduction stage, where the new culture that has been discovered has not been known in depth. This is why this first phase is still called the joy phase" (Indra, 2015).
After trying to get to know the new environment, each informant experienced different problems. The first problem that comes up is language. They deal with these language differences by learning, but in different ways. This language ability is very important because it determines the position of the informant in his new environment. Informants need to master the language to be able to communicate with local communities in order to understand their culture and participate in their activities so that informants can become part of the new environment (Sihabudin, 2011).

The second problem faced by informants is food. The main food in Taiwan is pork, while one of the informants is a Muslim. The informant had difficulty finding food due to language limitations to ask local residents where the halal food seller was. The other two informants are Christians, so they are not too burdened with food because they are used to eating pork. Even so, the two informants had difficulty using cutlery because Taiwanese culture is eating using chopsticks.

The third problem that the informants face is about clothing. The dress trend in Taiwan is different from Indonesia, where they have an expressive dress culture that makes people free to express themselves with their clothes. Classified as polite or not a dress, Taiwan has its own standards. In contrast to Indonesia, which emphasizes clothes that are not open and free to use any kind of footwear. Taiwan actually does not attach importance to clothing, but instead emphasizes footwear. The three informants revealed that the polite measure in Taiwan is when someone wears sneakers (sneakers).

The fourth problem is daily activities. The informants found some daily activities that became a culture for Taiwanese people which they thought were unusual. Included in this daily activity are the habit of rarely bathing, the culture of napping, the culture of collecting shopping receipts, and the toilet. Toilets are not a culture, but the informant explained that the state of toilets in Taiwan has changed their habits.

In terms of rarely bathing, one informant followed the Taiwanese habit. Two informants did not understand the reason behind this habit and could not follow the habit that was considered negative. In the nap culture, only one informant did it because he worked in a place that had a rule that naps coincided with office lunch time. The other two informants did not experience this, but they were aware of the existence of this culture in several offices. Then in the culture of collecting shopping receipts, the three informants did not follow the culture because they were not used to participating in the lottery which has become Taiwanese culture. Informants prefer to give it to a friend or put it in a 'charity box'. Then in terms of toilets, in Taiwan only squat toilets are available, which are much different from the squat toilets in Indonesia. There are toilet seats, of course, but they are very rare. This toilet is a problem for informants because it does not use water, 
of course this is not comfortable for informants who are used to using toilets in Indonesia. As the previous writer said, toilets are not a culture, but this toilet problem will change the informants' habits which the writer will reveal in the recovery period. The point is, as explained above by the author, this crisis period is a time of finding things that make informants uncomfortable.

After the informant tried to get to know the cultures that exist in Taiwan, the informant began to try to change his habits in order to begin to adjust to the reality in the new environment. Each informant has his own way, for example, as one informant brought a water bottle to the toilet because he was not used to dry tissue. Two other informants also brought wet wipes because they were considered more acceptable than dry tissues. The condition of the informants in the toilet problem shows that they are the type of cultural shocker, the adjuster, namely the type of individual who modifies his behavior to fit new habits. Another thing is an informant who tries to take part in office activities with an effort to blend in and also participates in campus events as a form of participation, this informant belongs to the type of cultural shocker, the participators, namely the type of individuals who try to be optimal in their work and work hard to get out of school. comfort zone where values apply in a new environment. The stage that has been passed by this informant is the recovery period. The behavior of the informants at this stage is in line with Tang T. Heng's expression in the theory he developed, namely the hybrid sociocultural framework theory (Heng, 2019).

The last stage after the recovery period is the adaptation period. Here, informants explain how they can adapt in a new environment. From the results of the interviews, the authors get a description of the condition of the informants in the current adaptation process, where there are two informants who reveal that they have successfully adapted to Taiwanese culture and there is one informant who feels that they are still in the process of adapting. Each individual has their own way to adapt in their environment, it all depends on their ability to face new things. Informants learn to develop not only from one culture, but from the meeting of two cultures, namely Indonesian culture and Taiwanese culture (Heng, 2019).

It doesn't stop there, one of the two informants in this study experienced reverse culture shock, a form of culture shock that occurs when a person returns to his/her original area after a long stay in another place with a new culture. This was experienced by an informant who returned to Indonesia after two years in Taiwan. The way Indonesians eat is using a spoon and fork or using their hands. However, the informant could not eat using a spoon and fork or with his hands as usual because he automatically used chopsticks, a custom in Taiwan (Indra, 2015).

The condition of the informants who experienced culture shock reverse has given an illustration that the process of culture shock will continue to rotate. Samovar said that the stages of culture shock will continue to repeat itself as individuals continue to encounter new things in their environment.

\section{Covid-19 Self Quarantine Indonesian Students in Taiwan}

Apart from culture, this research also reveals the Covid-19 phenomenon that was endemic in China at the end of December 2020, where in this phenomenon there was a case of a Taiwanese student who wanted to be sent back to Indonesia, and the problem was the location of Taiwan which is very close to China.

Taiwan has imposed a self-quarantine regulation in early 2020, before Indonesia had a Covid-19 case. The preventive movement raises questions about the condition of students from Indonesia during the self-quarantine. From the results of interviews, students from Indonesia in Taiwan did not experience a change in the way they communicate during the Covid-19 outbreak. The selfquarantine regulation for two weeks had no impact on their academic activities because it coincided with the winter vacation and the Chinese New Year holiday. During the self-quarantine regulations, each informant obeys the rules by staying at home and only going out for essential things. Here, the informants classified going to the office and buying food as important.

After the self-quarantine was completed, social distancing regulations were enforced because activities were running normally in Taiwan. Students also study as usual and have face-to-face contact with classmates and lecturers. Even so, their activities run as usual with the condition that they must carry out procedures such as wearing a mask every time they go to public places, checking their temperature every time they want to enter campus gates, bringing alcohol to clean their hands after leaving public places, washing their hands at all times, and keeping a distance from sitting in public places. classroom, at the diner, or in any other public place.

\section{CONCLUSION}

This study found that the adaptations made by Indonesian students related to the new culture in Taiwan and the current Covid-19 condition will lead them to a better communication relationship or vice versa. In terms of adapting to the new culture in Taiwan, students from Indonesia have begun to be accepted by the new environment and two of the informants have felt that they have successfully adapted, which means they have good communication relationships with Taiwanese students and other local communities. In terms of adapting to the current epidemic of Covid-19, good communication relations have been implemented. This is marked by the orderliness of the Taiwanese community in complying with self-quarantine and social distancing regulations. This good communication relationship has yielded good results in the prevention of Covid-19 cases and has been proven from safe Taiwan with the lowest cases in Asia. 


\section{REFERENCES}

Badan Pusat Statistik. (2018). Satistika Pendidikan. Badan Pusat Statistik. https:// www.bps.go.id/publication/2018/12/06/ a 65 b526c119ce8f799e 5 ea $63 /$ statistikpendidikan-2018.html

Bates, C., \& Bates, L.-L. (2005). Culture Shock! Taiwan: A Survival Guide to Customs and Etiquette (Culture Shock! Guides). Marshall Cavendish Editions.

bbc.com. (2020). Virus corona: Mahasiswa Indonesia di Wuhan ingin dievakuasi, Kemlu tunggu kebijakan pemerintah China. BBB News Indonesia. https:// www.bbc.com/indonesia/indonesia-51255468

Creswell, J. . (2017). Qualitative Inquiry and Research Design: Choosing among Five Tradition (4th ed.). Sage Publications.

Devita, M., Hidayah, N., \& Hendrastomo, G. (2015). Fenomena Culture Shock (Gegar Budaya) Pada Mahasiswa Perantauan Di Yogyakarta. Jurnal Pendidikan Sosiologi, 5(3), 1-15. https://adoc.pub/ nur-hidayah-dan-grendi-hendrastomo-uny.html

Habibi, N. (2020). Mahasiswa Indonesia di China Kuliah Jarak Jauh karena Corona. Republika.Co.Id. https:// www.republika.co.id/berita/q5s5ln428/mahasiswaindonesia-di-china-kuliah-jarak-jauh-karena-corona

Hale, E. (2020). How to control the spread of the coronavirus: Lessons from Taiwan. Aljazeera.Com. https://www.aljazeera.com/news/2020/3/7/howto-control-the-spread-of-the-coronavirus-lessonsfrom-taiwan

Heng, T. T. (2019). Understanding the Heterogeneity of International Students' Experiences: A Case Study of Chinese International Students in U.S. Universities. Journal of Studies in International Education, 23(5), 607-623. https://doi.org/https:// doi.org/10.1177/1028315319829880
Indra, M. M. (2015). Adaptasi Komunikasi dalam Menghadapi Culture Shock pada Mahasiswa Perantau (Studi Fenomenologi Adaptasi Mahasiswa Universitas Paramadina dalam Menghadapi Gegar Budaya) [Universitas Multimedia Nusantara]. https://kc.umn.ac.id/846/1/HALAMAN AWAL.pdf

Prasasti, G. D. (2020). COVID-19, Nama Resmi untuk Infeksi Novel Coronavirus. Liputan6.Com. https:// www.liputan6.com/health/read/4176849/covid-19nama-resmi-untuk-infeksi-novel-coronavirus

Prima, E. (2020). Taiwan Kembali Laporkan Nihil Kasus COVID-19 Baru. Tempo.Co. https://tekno.tempo. co/read/1331749/taiwan-kembali-laporkan-nihilkasus-covid-19-baru/full\&view $=$ ok

Rahayu, E. M. (2019). Cara Baru Bertemu Konsultan Pendidikan dengan Aplikasi Sun Education. Swa. Co.Id. https://swa.co.id/swa/trends/cara-barubertemu-konsultan-pendidikan-dengan-aplikasisun-education

Sagita, N. S. (2020). Nol Kasus Baru untuk Pertama Kalinya, Bagaimana Taiwan Hadapi Pandemi Corona? DetikHealth. https://health.detik.com/ berita-detikhealth/d-4977889/nol-kasus-baruuntuk-pertama-kalinya-bagaimana-taiwan-hadapipandemi-corona

Sihabudin, A. (2011). Komunikasi antarbudaya: suatu perspektif multidimensi. Bumi Aksara.

Warden, C. J. (1936). The Emergence of Human Culture. The Macmillan.

worldomater. (2020). Coronavirus Cases. Worldometers. Info. https://www.worldometers.info/coronavirus/

Wulandari, R., \& Rahmi, A. (2018). Relasi Interpersonal dalam Psikologi Komunikasi. Islamic Comunication Journal, 03(1), 56-73. https:// www.journal.walisongo.ac.id/index.php/icj/article/ download/2678/1686 